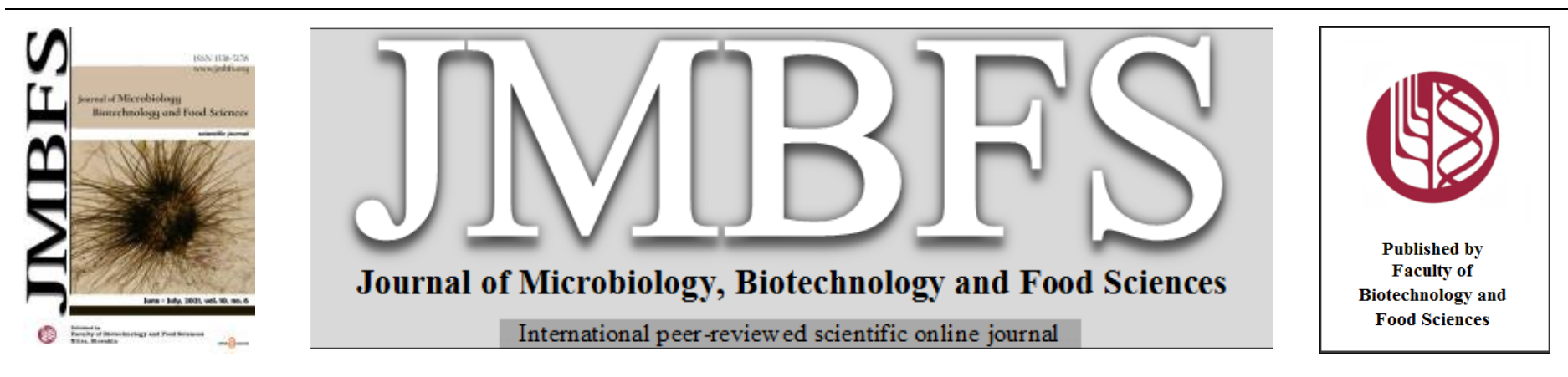

\title{
RELATIONSHIP BETWEEN CLIMATE CHANGE AND WINE QUALITY IN THE SLOVACKO SUBREGION AS A SUPPORT TO MANAGERIAL AND MARKETING DECISION MAKING
}

\author{
Tomáš Jeřábek $*^{l}$, Pavel Tvrznik ${ }^{l}$, Zdeněk Málek ${ }^{1}$, Miroslav Fišera ${ }^{l}$, Lenka Fišerová2, Stanislav Kráčmar ${ }^{1}$ \\ Address(es): \\ ${ }^{1}$ College of Business and Hotel Management Brno, Bosonožská 9, 62500 Brno, Czech Republic, +420 547218247. \\ ${ }^{2}$ Brno University of Technology, Faculty of Chemistry, Institute for Chemistry and Technology of Environmental Protection, Purkyňova 118, 61200 Brno, Czech \\ Republic.
}

*Corresponding author: jerabek@vsoh.cz

https://doi.org/10.15414/jmbfs.4682

\section{ARTICLE INFO}

Received 15. 2. 2021

Revised 7. 4. 2021

Accepted 16. 4. 2021

Published 1. 6. 2021

Regular article OPEN $\partial_{\text {ACCESS }}$

\begin{abstract}
Wine grapes are highly sensitive to changes in climate. The aim of the study was to evaluate the influence of selected climatic variables such as air temperature, total precipitation and the North Atlantic Oscillation Index on wine quality. This effect was monitored in individual phenological stages of grapevine plant growth; the monitoring was done separately for each of the selected wine varieties. The following varieties were subjected to evaluation: Pinot Gris, Riesling, Welschriesling, Pinot Blanc and Müller Thurgau from the Slovacko wine subregion of the Czech Republic. The long-term trend in climate development was also analysed through two bioclimatic indices. Our results show statistically significant effects of climate change on wine quality during various phenological stages in the Slovacko wine subregion. The effect of air temperatures on wine quality during the first phenological stage proved to be either negative (for the Müller Thurgau, Welschriesling and Riesling varieties) or statistically insignificant (for the Pinot Gris and Pinot Blanc varieties). For the second, third, and fourth phenological stages, the effect of air temperatures was positive for most of the analysed varieties. The statistically significant effect of precipitation on wine quality was confirmed for both Müller Thurgau and Riesling. During the first phenological phase, this effect proves to be positive, while for the other phenological stages the precipitation has a negative influence on the wine quality. The effect of the North Atlantic Oscillation Index (NAOI) shows a positive impact on the Pinot Gris variety during the first phenological stage. For the second and third phenological stages, the negative influence of the NAOI on the wine quality was confirmed for both Müller Thurgau and Pinot Blanc. Furthermore, the results show a slight, statistically significant, growth trend of the Winkler index. The growth trend of the hydrothermal index is statistically insignificant, which is probably due to the decrease in precipitation.
\end{abstract}

\section{INTRODUCTION}

The cultivation of vines is influenced by three main factors, namely by climate, soil and variety (Blij, 1983). These factors affect the style of wine that is produced by a given wine region. (White et al., 2009). On the other hand, the year-on-year variability of wine quality is mainly the result of short-term climate variability, such as average temperatures during the growing season of the vine (Lorenzo et al., 2013).

The vine is highly sensitive to climate. Too many sunny days during the growing season cause the accumulation of excess sugar and the subsequent production of alcoholic and heavy wines. Jones et al. (2005) state that most wine-growing areas are located in places where average temperatures range from $12^{\circ} \mathrm{C}$ to $22^{\circ} \mathrm{C}$ during the growing season. The recommended average temperatures for the growing season for different varieties are given by Pavloušek (2009). Jones and Webb (2010) state that the effects of climate change will not be the same in all varieties and regions. These effects are likely to be related to climate thresholds. If the region has an average temperature of $15^{\circ} \mathrm{C}$ during the growing season and this temperature increases by $1^{\circ} \mathrm{C}$, then this area is more climate-friendly for the maturation of selected varieties, while it becomes less suitable for others. If the magnitude of warming is $2^{\circ} \mathrm{C}$ or greater, then the area may potentially shift to another type of climatic maturity. For example, it is recommended that the varieties Riesling or Gewürztraminer be grown in areas where temperatures range between $15-17^{\circ} \mathrm{C}$ during the growing season. Thus, shifting climatic conditions can potentially affect the wine industry (Mozell and Thach, 2014).

Information on climate change is utilised in marketing and it specifically influences awareness of the wine quality produced in a given year. The perception of wine quality depends on individual evaluation, which is influenced by the complexity of the information provided. This information is becoming a major factor influencing consumer shopping behaviour. As Lockshin (2012) mentions, the consumer perception of the quality of wine is given both by the point evaluation of its quality and by its price. Information on the climate of a given year, wine quality and price are becoming fundamental determinants that influence consumers' shopping behaviour.

The influence of climate on the wine quality has been dealt with in many papers (Jones and Storchmann, 2001; Storchmann, 2005; Lorenzo et al., 2013; Almaraz, 2015; Poř́zka and Diviš, 2017). However, the vast majority of them have not addressed specific varieties. In all cases, the authors conclude that climate fluctuations have an impact on the quality of wine, as well as on the organoleptic properties of grapes.

Ashenfelter (2010) found that the temperatures of the growing season and precipitation during the harvest period significantly affect the quality of wines produced in the Bordeaux region. Jones and Storchmann (2001) came to the conclusion that dry summers result in high sugar and low acid levels in grapes at harvest which in turn lead to higher quality of wines. Soar et al. (2008) used a chi-squared test to investigate climatic influences on long-term records of vintage scores from four climatically contrasting wine growing regions of Australia. Baciocco et al. (2014) analysed the key climatic factors, derived for the entire growing season and for critical phenological stages, which distinguish between high- and low-ranked vintages for both red and white wines in Bordeaux, France. Van Leeuwen et al. (2009) determined the impact of water deficit stress on grapevine shoot growth, berry weight, grape composition and overall vintage quality; the specific factors were investigated in Bordeaux vineyards. Salinger et al. (2015) examined climatic factors and weather type frequencies affecting Tuscany to discriminate between vintages ranked into the upper- and lowerquartile years as a consensus from six rating sources of Chianti wine during the period 1980 to 2011. Lorenzo et al. (2013) researched the influence of several climatic variables, on grape production in the different phenological stages and on wine quality in Ri'as Baixas. Almaraz (2015), for data from the Bordeaux 
wine region, developed a time-varying coefficients regression approach that is capable of partitioning the temporal effects of temperature on wine quality across sequential grape growing seasons, accounting for wine-rating uncertainty.

The aim of this study is to evaluate the influence of selected climatic variables such as air temperature, total precipitation and the North Atlantic Oscillation Index on wine quality. This effect is monitored in individual phenological stages of grapevine plant and separately for each of the selected varieties. The following varieties were subjected to monitoring: Pinot Gris (PG), Riesling (R), Welschriesling (WR), Pinot Blanc (PB) and Müller Thurgau (MT) from the Slovacko wine subregion of the Czech Republic. The long-term trend in climate development is also analysed through two bioclimatic indices.

\section{MATERIAL AND METHODS}

The impacts of climatic changes in temperature and precipitation on wine quality were monitored within the Slovacko wine subregion. This subarea is considered one of the four subregions of the Moravian wine growing region. The Slovacko subregion covers 4,514 hectares of vineyards and includes $24.1 \%$ of the vineyards in the Czech Republic. The subregion has very heterogeneous natura vine growing conditions. According to climatological studies, drought at the beginning and end of the growing season is typical for most of the area However, drought in summer is no exception (Rožnovský et al., 2010)

Wine quality can be defined as the average rating assigned by wine experts to a vintage. We use the results of point organoleptic evaluation of wine samples during the period 2002 to 2019 . The growing season of the analysed wines covers the period from 2001 to 2018. The evaluation is based on a one-off tasting of individual varieties by a group of expert evaluators. A 100-point rating system, which classifies wines into five categories, from excellent wine $(90<$ points) to below-average wines ( $<61$ points), was used.

Climatic data were related to individual phenological phases of the grapevine The onset periods of the individual phenological phases were adjusted with respect to the analysed wine subregion (Zahradníček, 2008):

1. Start of pruning - it occurs when the bushes are restored after the winter season. During the first half of the spring period (end of March, April) the vegetation activity of the grapevine is restored.

2. Emergence of buds and blossom - the process of leaf development; looking at the leaf face from above, you can already see most of the petiole and the entire area of the leaf blade. This stage occurs in May.

3. General flowering - at this stage, when looking at the flower from the side the threads of the stamens or at least the lower part of them are visible. First, the flowers in the lower part of the lath bloom can be seen in this way and then the bloom continues towards its top. This stage occurs in June.

4. Hanging grapes - this is the stage when the grape has taken a more or less vertical position. The phase occurs in the second half of June and covers the period until harvest.

Daily climatic data from 2001 to 2018 were obtained from the Czech Meteorological Institute (https://www.chmi.cz/historicka-data/pocasi/dennidata/Denni-data-dle-Z.-123-1998-Sb). We chose two stations located in the Slovacko subregion (Strážnice and Ždánice). The average, maximum and minimum daily temperatures and daily precipitations for each phenological stage were used. In addition, the effect of atmospheric circulation on wine quality was monitored. The intensity of the atmospheric circulation can be measured by means of the zonal circulation index (Elektronický meteorologický slovník, 2017). The most prominent model of circulation in Europe is North Atlantic Oscillation (NAO). We use North Atlantic Oscillation index (NAOI). When the NAOI is well above normal value, there is an increased chance that seasonal temperatures will be higher than the normal ones in Europe. When the NAO index is well below normal, the tendencies are generally opposite (Martineau et al., 2020). Monthly values of NAOI from 2001 to 2018 were obtained from Climate Prediction Center (http://www.cpc.ncep.noaa.gov/index.php). NAOI values were determined for each phenological stage.

Furthermore, in order to analyse the long-term trend of climate development, two bioclimatic indices were calculated. They provide the information about climate changes impact on viticulture (Malheiro et al., 2010). The bioclimatic indices are also commonly used in vineyard zoning. One of the most widely used indices is temperature based Winkler index (WI), using a growing degree base of $10^{\circ} \mathrm{C}$ to place viticulture in the context of climate suitability (Winkler et al., 1974).

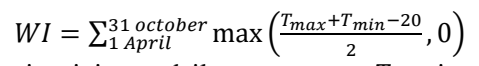

where $T_{\min }$ is minimum daily temperature, $T_{\max }$ is maximum daily temperature. The Hydrothermic Index of Branas, Bernon and Levadoux (BBL) measures the influence of temperature and precipitation on wine quality (Branas et al., 1946).

$$
B B L=\sum_{1 \text { April }}^{31 \text { Augt }} T_{m} P_{m}
$$

where $T_{m}$ is average monthly temperature, $P_{m}$ is monthly accumulated precipitation (mm).

All variables used were first analysed for the presence of a trend using the MannKendall nonparametric test (Mann, 1945; Kendall, 1970). The variables with a statically significant trend were linearly detrended. For such adjusted variables, a linear relationship was found between climate change and wine quality based on calculations implemented. For this purpose, the Pearson correlation coefficient was used. Statistical significance of correlation was assessed by Student's t-test. In order to further specify the relationship between the climatic (independent) variable and the quality of the wine (dependent variable), a linear regression model was used. After the model is estimated, several diagnostic tests have to be done (Maltloff, 2017). These diagnostic tests are used to check for the specification of the model, as well as for the possible problems of heteroscedasticity, autocorrelation and linearity confirmation in the estimated regression model. For that purpose, we employed Ramsey RESET (Ramsey, 1969), Ljung-Box Serial Correlation (LB) test (Ljung and Box, 1978), BreuschPagan Heteroscedasticity (BP) test (Breusch and Pagan, 1979), Shapiro-Wilk normality (SW) test of the model residuals (Shapiro and Wilk, 1965).

The analysis of the development trend of bioclimatic indices was performed through the identification of structural breaks that represent unexpected changes over time in the parameters of regression models. We employed Chow (1960) test that examines agreement between sets of coefficients in two long regressions.

\section{RESULTS}

Table 1 shows the correlation coefficients for the relationships between wine quality and each of the climatic variables. We considered the four main phenological periods of start of pruning, emergence of buds and blossom, general flowering and hanging grapes. For each of the varieties, the t-test showed statistically significant dependencies. The data indicate that the influence of climatic variables on wine quality varies for the monitored varieties. For example, most varieties are positively affected by temperatures in the second, third and fourth phenological stages, while the effect of temperatures is negative during the first phenological stage.

In order to verify the found statistically significant relationships, a linear regression model was used. For this purpose, 17 linear regression models were estimated. Specifically, seven models for the MT variety, four models for the WR variety, one model for the PG variety, three models for the PB variety and two models for the $\mathrm{R}$ variety. The linear specification of all models was not rejected (at the 5\% significance level) by the Ramsey RESET test. Using the Ljung-Box test, the null hypothesis of no autocorrelation was not rejected at the 5\% significance level for all models. Homoskedasticity of all models was not rejected at the $5 \%$ significance level by the Breusch-Pagan test. The residue normality of all models was not rejected at the $5 \%$ significance level by the Shapiro-Wilk test.

Table 2 presents statistically significant results for the MT variety. The table shows that in the first phenological stage, the values of minimum and average temperatures had a negative effect on the wine quality. The above result is probably due to the fact that the temperatures can significantly affect the future development of plants at the beginning of pruning stage. In particular, low temperatures may limit the future development of assimilation in leaves. Within the first stage, there is also a statistically significant positive correlation between the wine quality and amount of precipitation. The probable reason is that ample rainfall conditions cause a faster onset of green matter. This result indicates the importance of precipitations during the first phenological stage for the MT variety.

Due to climate variability, there are changes in the spatial and temporal distribution of temperatures, precipitation and other climatic variables. For this reason, the North Atlantic Oscillation Index (NAOI) was also analysed. Positive NAOI values are caused by the positive phase of the North Atlantic Oscillation, which is associated with higher temperatures in Central Europe. In the case of negative values, the opposite applies. Values of NAOI for each of the phenological stages are presented in Figure 1. Based on the above figures, the predominance of the positive NAOI values is apparent in first phenological stage, while for the other phenological phases negative values prevail. For the MT variety, NAOI during the emergence of buds and blossom stage has a positive influence on wine quality.

Both average and maximum temperatures during the general flowering stage show a positive effect on the wine quality for MT variety, which occurs probably due to the fact that higher temperatures for this stage have a positive effect on both amount and flow of inflorescences. The amount of precipitation during general flowering stage had a negative effect on wine quality for the MT variety. In contrast, for the second, the third and the fourth phenological stages, negative NAOI values prevailed during the observed period; they are the cause of colder weather. 
Table 1 Correlation coefficients for the relationships between wine quality and each of the climatic variables

\begin{tabular}{|c|c|c|c|c|c|c|}
\hline Variable & Stage & MT & $\mathrm{R}$ & WR & PG & PB \\
\hline \multirow{4}{*}{ Tmin } & 1 & $-0.58 * * *$ & -0.3 & $-0.44^{* *}$ & 0.26 & 0.02 \\
\hline & 2 & -0.28 & -0.11 & 0.2 & -0.36 & -0.21 \\
\hline & 3 & 0.13 & 0.05 & -0.14 & 0.32 & 0.05 \\
\hline & 4 & -0.33 & 0.02 & -0.03 & 0.29 & 0.18 \\
\hline \multirow{4}{*}{ Tave } & 1 & $-0.58 * * *$ & $-0.48 * *$ & -0.12 & -0.02 & -0.22 \\
\hline & 2 & 0.03 & -0.19 & 0.33 & -0.13 & 0.08 \\
\hline & 3 & $0.58 * * *$ & -0.14 & 0.25 & 0.35 & -0.05 \\
\hline & 4 & -0.06 & -0.39 & $0.62^{* * *} *$ & 0.21 & -0.35 \\
\hline \multirow{4}{*}{ Tmax } & 1 & 0.08 & $-0.64 * * *$ & 0.2 & -0.09 & -0.41 \\
\hline & 2 & -0.12 & 0.28 & 0.16 & -0.1 & $0.5^{* *}$ \\
\hline & 3 & $0.53 * *$ & 0.36 & 0.18 & -0.33 & 0.22 \\
\hline & 4 & -0.32 & -0.34 & 0.12 & 0.34 & $0.48^{* *} *$ \\
\hline \multirow{4}{*}{ NAOI } & 1 & 0.05 & -0.23 & 0.02 & $0.49 * *$ & -0.42 \\
\hline & 2 & $-0.48^{* *}$ & -0.33 & 0.25 & -0.22 & -0.33 \\
\hline & 3 & 0.07 & 0.01 & 0.22 & -0.24 & $-0.47 * *$ \\
\hline & 4 & -0.19 & -0.11 & -0.19 & -0.26 & -0.15 \\
\hline \multirow{4}{*}{$\mathrm{P}$} & 1 & $0.58 * * *$ & 0.04 & -0.3 & 0.28 & 0.03 \\
\hline & 2 & 0.07 & 0 & $-0.59 * * *$ & -0.04 & -0.13 \\
\hline & 3 & $-0.44^{* *}$ & -0.07 & -0.28 & -0.39 & 0.18 \\
\hline & 4 & -0.1 & 0.16 & $-0.71 * * *$ & 0.24 & 0.25 \\
\hline \multicolumn{7}{|c|}{$\begin{array}{l}\text { Note: We use ** to indicate significance at the } 5 \% \text { ( } p \text {-value ranges from } 0.05 \text { to } 0.01) \text {, *** to indicate } \\
\text { significance at the } 1 \%(p \text {-value }<0.01) \text {. Tmin: minimum temperature, Tave: average temperature, Tmax: } \\
\text { maximum temperature, NAOI: index of North Atlantic oscillation, P: accumulated precipitation, Stage: } \\
\text { phenological stage of grapevine plant, Pinot Gris }(P G), \text { Riesling }(R) \text {, Welschriesling }(W R) \text {, Pinot Blanc } \\
(P N) \text { and Müller Thurgau }(M T) \text {. }\end{array}$} \\
\hline
\end{tabular}

Table 2 Results for Müller-Thurgau variety.

\begin{tabular}{lccccccc}
\hline Wine & \multicolumn{7}{c}{ MT } \\
\hline Variable & Tmin & Tave & $\mathrm{P}$ & NAOI & Tave & Tmax & P \\
\cline { 2 - 8 } Stage & 1 & 1 & 1 & 2 & 3 & 3 & 3 \\
Correlation & $-0.58^{* * *}$ & $-0.58^{* * *}$ & $0.58^{* * *}$ & $-0.48^{* *}$ & $0.58^{* * *}$ & $0.53 * *$ & $-0.44 * *$ \\
Rams. (p-value) & 0.15 & 0.79 & 0.33 & 0.65 & 0.21 & 0.41 & 0.28 \\
LB (p-value) & 0.81 & 0.55 & 0.88 & 0.69 & 0.52 & 0.8 & 0.81 \\
BP (p-value) & 0.13 & 0.01 & 0.11 & 0.12 & 0.13 & 0.22 & 0.16 \\
SW (p-value) & 0.91 & 0.41 & 0.13 & 0.23 & 0.47 & 0.24 & 0.19 \\
\hline
\end{tabular}

Note: We use ** to indicate significance at the 5\% (p-value 0.05 to 0.01 ), *** to indicate significance at the $1 \%$ (pvalue 0.01). Tmin: minimum temperature, Tave: average temperature, Tmax: maximum temperature, NAOI: index of North Atlantic oscillation, P: accumulated precipitation, Stage: phenological stage of grapevine plant, Rams. (p-value): $p$ value of Ramsey RESET test, LB (p-value): p-value of Ljung-Box test, BP (p-value):p-value of Breusch-Pagan test, SW ( $p$ value): p-value of Shapiro-Wilk test

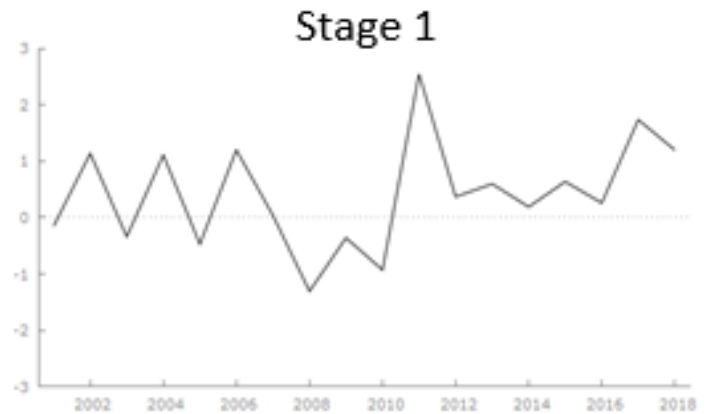

Stage 3

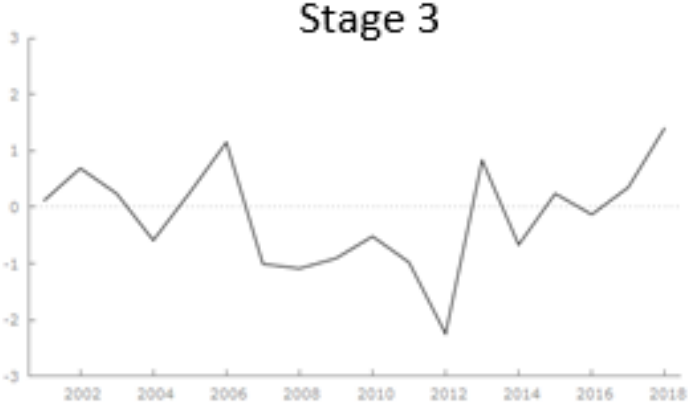

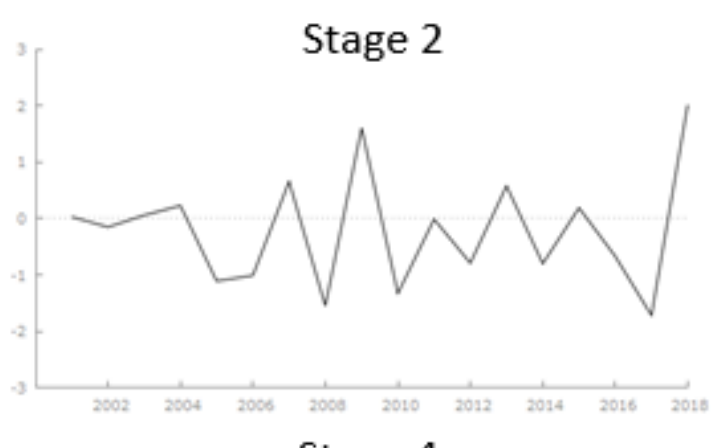

Stage 4

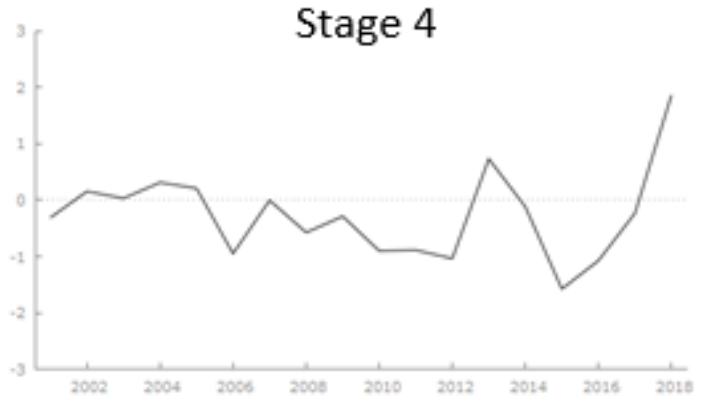

Figure 1 Time series of NAOI for the period from 2001 to 2018 during all phenological stages.

Table 3 presents the results relating to the Welschriesling variety. The negative effect of minimum temperatures during the start of pruning stage is evident. ;it results from the fact that auxins begin to form in the winter eye during the first phenological stage. Auxins play a cardinal role in coordination of growth and are essential for plant body development. At the same time, the concentration of abscisic acid acting as a growth inhibitor decreases.

Precipitation showed the negative correlation with quality of the WR wine during the emergence of buds and blossom and in the hanging grapes stages. Significant 
rains, especially for the fourth stage, can cause the grapes to crack with subsequent rot. This can adversely affect the fermentation process.

Table 3 Results for the WR variety

\begin{tabular}{lcccc}
\hline Wine & \multicolumn{5}{c}{ WR } \\
\hline Variable & Tmin & $\mathrm{P}$ & Tave & $\mathrm{P}$ \\
\cline { 2 - 5 } Stage & 1 & 2 & 4 & 4 \\
correlation & $-0.44^{* *}$ & $-0.59^{* * *}$ & $0.62^{* * *}$ & $-0.71^{* * *}$ \\
Rams. (p-value) & 0.9 & 0.91 & 0.61 & 0.79 \\
LB (p-value) & 0.8 & 0.21 & 0.48 & 0.23 \\
BP (p-value) & 0.95 & 0.44 & 0.88 & 0.59 \\
SW (p-value) & 0.83 & 0.55 & 0.09 & 0.57 \\
\hline
\end{tabular}

Note: We use ** to indicate significance at the $5 \%$ (p-value 0.05 to 0.01$)$, *** to indicate significance at the $1 \%$ (p-value $<0.01)$. Tmin: minimum temperature, Tave: average temperature, $P$ : accumulated precipitation, Stage: phenological stage of grapevine plant, Rams. (p-value): p-value of Ramsey RESET test, LB (pvalue): p-value of Ljung-Box test, BP (p-value: p-value of Breusch-Pagan test, $S W$ (p-value): p-value of Shapiro-Wilk test.

Table 4 shows the results for the three varieties (PB, PG and R). Quality of the PG variety is positively influenced by the development values of NAOI during the start of pruning stage. This result is based on the predominant positive values of this index for the first phenological stage. The quality of PB variety is positively influenced by occurrence of maximum temperatures during the emergence of buds and blossom stage. During the general flowering stage, NAOI demonstrates a positive correlation with wine quality of the PB variety. Due to the negative values of NAOI during the above stage, this negativity is probably caused by lower temperatures. For the hanging grapes stage, the positive effect of maximum temperatures on wine quality of $\mathrm{PB}$ is evident. Wine quality of the $\mathrm{R}$ variety is statistically significantly affected by climate change only during the start of pruning stage. Specifically, a negative effect of average and maximum temperatures is shown in the stage.

Global warming leads to rising temperatures. Rising temperatures could, in the long term, demonstrate changes in the vine varieties that are suitable for cultivation in these areas. Regarding strategic planning, it is very important for winemakers to know the trends, not only of temperatures but also of precipitation. For this purpose, the developments of two bioclimatic indices are presented, namely of the Winkler (WI) and the hydrothermic index (BBL) for the period from 1961 to 2018 , see figure 2 . The figure also shows the growth trend for both indices over last 57 years.

In order to determine the impact of climatic change, the growth trends of the both indices were analysed. The data show a slight increase in the values of the Winkler index, demonstrating a statistically significant trend, at the $1 \%$ level of significance, which is due to the positive development of temperatures. To provide a detailed trend analysis, we identify structural changes in the trend using linear regression. The explanatory variable in this case is constant and it shows a trend. The research focuses on structural changes in the trend slope during the above period. The results show a statistically significant (at $7 \%$ level of significance), positive structural break in 1988. Specifically, until 1988, the growth trend had not been statistically significant. In 1988, there was a positive change in the trend slope. Noticeably, but statistically significantly, the growing trend of the Winkler index indicates a continuation of temperature rise. Thus, in the future, there could be problems with growing selected white varieties in this area.

The development of the BBL index shows a significant variance due to irregular precipitation. Furthermore, for specific time periods, this index reaches relatively high values. It means that vineyards in this area may be exposed to fungal diseases. The growth trend of BBL index is statistically insignificant. Due to the fact that the BBL index is formed by changing temperatures and precipitation, the statistical insignificance of the trend may be caused by a gradual decreasing in amount of precipitation in the monitored area.

\begin{tabular}{|c|c|c|c|c|c|c|}
\hline Wine & PG & & $\mathrm{PB}$ & & & $\mathrm{R}$ \\
\hline Variable & NAO & Tmax & NAOI & Tmax & Tave & Tmax \\
\hline Stage & 1 & 2 & 3 & 4 & 1 & 1 \\
\hline correlation & $0.49 * *$ & $0.50 * *$ & $-0.47 * *$ & $0.48 * *$ & $-0.48 * *$ & $-0.64 * * *$ \\
\hline Rams. (p-value) & 0.80 & 0.8 & 0.49 & 0.19 & 0.39 & 0.28 \\
\hline LB (p-value) & 0.25 & 0.21 & 0.58 & 0.36 & 0.42 & 0.59 \\
\hline BP (p-value) & 0.34 & 0.64 & 0.77 & 0.85 & 0.56 & 0.79 \\
\hline SW (p-value) & 0.47 & 0.75 & 0.78 & 0.85 & 0.57 & 0.96 \\
\hline
\end{tabular}

WI

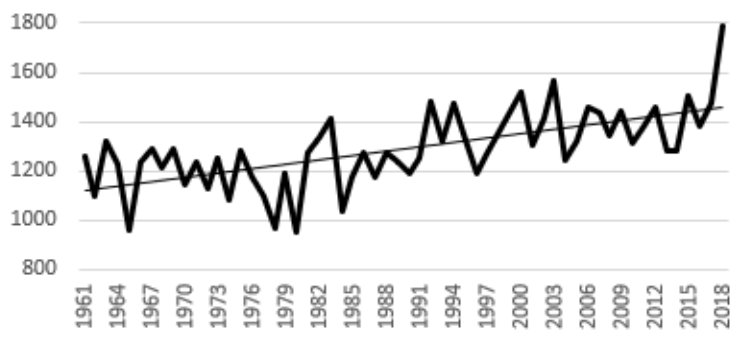

BBL

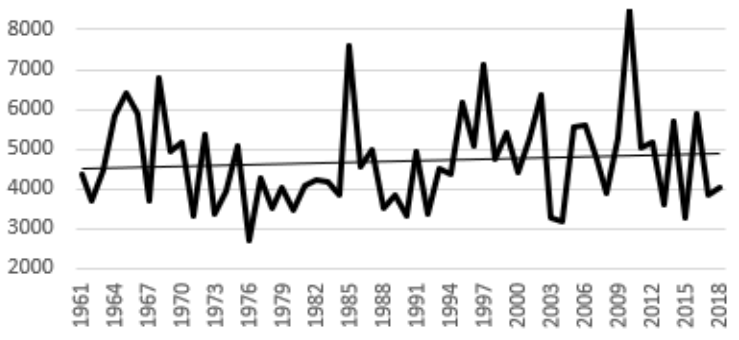

Figure 2 Time series and trends for Winkler index (WI) and hydrothermic index (BBL) for the period from 1961 to 2018.

\section{DISCUSSION AND SUMMARY}

The aim of this study was to evaluate the influence of selected climatic variables such as air temperature, total precipitation and the North Atlantic Oscillation Index on wine quality. This effect was monitored in individual phenological stages of grapevine plants separately for each of the selected varieties. The following varieties were subjected to evaluation: Pinot Gris (PG), Riesling (R), Welschriesling (WR), Pinot Blanc (PB) and Müller Thurgau (MT) from the Slovacko wine subregion of the Czech Republic. The long-term trend in climate development was also analysed through two bioclimatic indices.

The results show that the quality of all varieties is statistically significantly affected by at least some of the climatic variables. The individual phenological stages were found to show major differences. For example, if there is a statistically significant effect of the development of air temperatures on the wine quality during the first phenological stage, then this effect is negative. In particular, the negative effect of the development of minimum, average and maximum temperatures during the start of pruning stage was evident for the MT, $\mathrm{WR}$ and $\mathrm{R}$ varieties. The above finding results probably from the fact that the temperatures can significantly affect the future development of plants in the start of pruning stage. In particular, low temperatures may limit the future assimilation in leaves. In the case of the other three phenological stages, either no or a statistically significant positive effect on the wine quality is evident. This result was expected for all varieties. The vine is a thermophilic tree and, as stated by Kraus and Kraus (2012), at average vegetation temperatures below $10^{\circ} \mathrm{C}$, the so-called vegetation zero, the vine plant does not sprout or grow.

The results are in line with most studies focused on European wine regions. Nemani et al. (2001) show that higher quality over the last 50 years has been influenced by a reduction in the incidence of frost. Lorenzo et al. (2013) found 
significant positive correlations between temperature and wine quality. In the case of the effect of precipitation, the situation is similar and depends on the variety of wine. The negative effect of precipitation on quality prevails, which is in line with results reported by Lorenzo et al. (2013), Baciocco et al. (2014), Mika et al. (2017). Our results show that the quality of the MT variety is negatively affected by precipitation during the general flowering stage. For the quality of the RV variety, precipitation has a negative effect during the general flowering and the hanging grapes stages. The reason is that significant rains, especially for the fourth stage, can cause the grapes to crack with subsequent rot However, for the MT variety, the results show a significantly positive correlation between wine quality and precipitation during the start of pruning stage. The probable reason is that ample rainfall conditions cause a faster onset of green matter. This result indicates the importance of precipitation during the first phenological stage for the MT variety.

According to Beranová and Huth (2012), the North Atlantic Oscillation (NAO) has a significant effect on the weather in the Czech Republic. Our results show a different influence during various phenological stages. During the first phenological stage, the effect of NAOI on wine quality is positive, while during the other three phenological stages, this effect is negative. The above finding results from the prevailing positive values of NAOI in the first phenologica stage; it brings warmer weather to Central Europe. In contrast, in the second to fourth phenological phases, negative NAOI values prevailed during the observed period, which is the cause of colder weather.

The results for bioclimatic indices are consistent with Navrátilová et al. (2021) Our findings show a slight, statistically significant, growth trend of the Winkler index. This trend indicates a continuing rise in temperatures. Thus, in the future there may be problems with growing selected white wine varieties in the analysed area. The hydrothermic index shows a significant variance due to irregular precipitation. Despite the rise of temperature, the growth trend of this index is statistically insignificant; the above occurs probably due to the gradual decrease in precipitation.

In terms of practical use, the results obtained cover three key factors. The first factor influences the system of work in the vineyard, especially in terms of designing the optimal time for treatment of vines and green work. The second factor optimizes the grape harvest with maximum use of knowledge of climatic conditions. The third factor represents the processing; it controls processes during the fermentation of the must, together with the system of its treatment. These three factors can partially eliminate possible negative climate impacts in a given year. Climate analysis and the ability to use the information obtained can become basic marketing prerequisites for the economic evaluation of wine production in individual years in the area. Due to climate change, quality of grapes will gradually reach the limits of the climatic area. Results of future research may indicate a possible exceedance of the climate threshold. Climate change will modify both the quality of the grapes required for the existing varieties and the wine-growing styles. These changes may force wine producers in selected regions to optimize the portfolio of varieties to be grown. Climate change is mirrored and will be reflected in the marketing and economic behaviour of wine producers.

\section{CONCLUSION}

Although the development of climate and its changes is uncertain, the climate also has a significant impact on the viability of wine production. It is thus very likely that climate change will bring about changes in the suitability of planted vine varieties. These changes will have a major impact on regional wine styles and cultures. Wine growers must learn to use climate change predictions in them of integrating them into harvest planning strategies. It will also be important to update practices in "basement technology", which can to some extent eliminate adverse climatic effects. Thus, precise meteorological analysis will play an increasingly important role in facilitating planning and adaptation to climate change in the future.

Our results show statistically significant effects of climate change on wine quality during various phenological stages in the Slovacko wine subregion. The effect of air temperatures on wine quality during the first phenological stage proved to be either negative (for the Müller Thurgau, Welschriesling and Riesling varieties) or statistically insignificant (for the Pinot Gris and Pinot Blanc varieties). For the second, third, and fourth phenological stages, the effect of ai temperatures was positive for most of the analysed varieties. The statistically significant effect of precipitation on wine quality was confirmed for both Müller Thurgau and Riesling. During the first phenological stage, this effect proved to be positive, while for the other phenological stages the elevated precipitation had a negative influence on the wine quality. The effect of the North Atlantic Oscillation Index (NAOI) was positive for the Pinot Gris variety during the first phenological stage. For the second and third phenological stages, the negative influence of the NAOI on the wine quality was confirmed for both Mülle Thurgau and Pinot Blanc. Furthermore, the results show a noticeable, statistically significant, growth trend of the Winkler index. The growth trend of the hydrothermal index is statistically insignificant, which is probably due to the decrease in precipitation.
Acknowledgments: The research this article reports on was implemented under the support of the operational Program called Research and Development for Innovations (Výzkum a vývoj pro inovace) that is co-funded by the European Fund for Regional Development (ERDF) and also subsidized from the state budget of the Czech Republic within the Centre of Polymer Systems Project (reg. n.: CZ.1.05/2.1.00/03.0111). It was also supported by the "2112 - Institutiona Support for the Development of Research Organizations" (Institucionáln podpora na rozvoj výzkumné organizace, project ID 22738) grant, subsidized by Brno University of Technology and granted by the Czech Ministry of Education (MŠMT).

\section{REFERENCES}

Almaraz, P. (2015). Bordeaux Wine Quality and Climate Fluctuations During the Last Century: Changing Temperatures and Changing Industry. Climate Research, 64(3), 187-199, [cit. 2021-01-29]. https://doi.org/10.3354/cr01314.

Ashenfelter, O. (2010). Predicting the Quality and Prices of Bordeaux Wine Journal of Wine Economics, 5(1), 40-52, [cit. 2021-01-30]. https://doi.org/10.1017/S193143610000136X.

Baciocco, K.E., Davis, R.E. \& Jones, G.V. (2014). Climate and Bordeaux Wine Quality: Identifying the Key Factors That Differentiate Vintages Based on Consensus Rankings. Journal of Wine Research, 25(2), 75-90, [cit. 2021-01-10]. https://doi.org/10.1080/09571264.2014.888649.

Beranová, R. \& Huntr, R. (2012). Time Variations of the Relationships Between the North Atlantic Oscillation and European Winter Temperature and Precipitation. Studia Geophysica et Geodaetica, 51(1), 575-590, [cit. 2021-0120]. https://doi.org/10.1007/s11200-007-0034-3.

de Blij, H.J. (1983). Geography of Viticulture: Rationale and Resource. Journal of Geography, 82(3), 112-121, [cit. 2021-01-03]. https://doi.org/10.1080/00221348308980792.

Borges, J., Real, A.C., Cabral, J.S. \& Jones, G.V. (2012). A New Method to Obtain a Consensus Ranking of a Region's Vintages' Quality. Journal of Wine Economics, 7(1), 88-107, [cit. 2021-01-17]. https://doi.org/10.1017/jwe.2012.7 Branas, J., Berton, G. \& Levadoux, L. (1946). Eléments de Viticulture Générale. Montpellier: École National d'Agriculture de Montpellier.

Breusch, T.S. \& Pagan, A.R. (2017). A Simple Test for Heteroskedasticity and Random Coefficient Variation. Econometrica, 47(5), 1287-1294, [cit. 2021-0119]. https://doi.org/10.2307/1911963.

Chow, G.C. (1960). Tests of Equality Between Sets of Coefficients in Two Linear Regressions. Econometrica, 28(3), 591- 605, [cit. 2021-01-30]. https://doi.org/10.2307/1910133.

Elektronický meteorologický slovník (2017) [online]. Meteorologický slovník výkladový a terminologický ČMeS, Available online: http://slovnik.cmes.cz

Freund, R.J., Wilson, W.J. \& Mohr, D.L. (2010). Statistical Methods. London Elsevier. ISBN 978-0123749703.

Jones, G. \& Storchmann, K. (2001). Wine Market Prices and Investment under Uncertainty: An econometric model for Bordeaux Crus Classés. Agricultural Economics, 26(1), 115-133, [cit. 2021-01-21]. https://doi.org/10.1016/S01695150(00)00102-X

Jones, G. \& Webb, L. (2010). Climate Change, Viticulture, and Wine: Challenges and Opportunities. Journal of Wine Research, 21(2/3), 103-106, [cit. 2021-0110]. https://doi.org/10.1080/09571264.2010.530091.

Jones, G., White, M., Cooper, O., Storchmann, K. Climate Change and Global Wine Quality. Climatic Change. 2005, 73(1). 319-343, [cit. 2021-01-25]. https://doi.org/10.1007/s10584-005-4704-2.

Kendall, M.G. (1970). Rank Correlation Methods. New York, NY: Oxford University Press. ISBN 978-0852641996.

Kraus, V. \& Kraus, V. (2012). Pěstujeme révu vinnou. Praha: Grada Publishing, a.s., 112 p. ISBN 978-80-247-3465-1.

Leeuwen, C. \& Darriet, P. (2016). The Impact of Climate Change on Viticulture and Wine Quality. Journal of Wine Economics, 11(1), 150-167, [cit. 2020-12-30]. https://doi.org/10.1017/jwe.2015.21.

Leeuwen, C., Trégoat, O., Choné, X., Bois, B., Pernet, D. \& Gaudilllere, J.P. (2009). Vine water status is a key factor in grape ripening and vintage quality for red Bordeaux wine. How can it be assessed for vineyard management purposes? Journal International des Sciences de la Vigne et du Vin., 43(3), 121-134, [cit 2021-01-25]. https://doi.org/10.20870/oeno-one.2009.43.3.798.

Ljung, G. \& Box, G. (1978). On a Measure of Lack of Fit in Time Series Models. Biometrika, 65(1), [cit. 2021-01-27]. https://doi.org/10.1093/biomet/65.2.297.

Lockshin, L. \& Corsi, A.M. (2012). Consumer Behaviour for Wine 2.0: A Review Since 2003 and Future Directions. Wine Economics and Policy, 1(1), 2 23, [cit. 2021-01-20]. https://doi.org/10.1016/j.wep.2012.11.003.

Lorenzo, M.N., Taboada, J.J., Lorenzo, J.F. \& Ramos, A.M. (2013). Influence of Climate on Grape Production and Wine Quality in the Rias Baixas, NorthWestern Spain. Regional Environmental Change,13, 887-896, [cit. 2020-12-20]. https://doi.org/10.1007/s10113-012-0387-1.

Malheiro, A.C., Santos, J.A., Fraga, H. \& Pinto, J.G. (2010). Climate Change Scenarios for Viticultural Zoning in Europe. Climate Research, 43(3), 163-177, [cit. 2021-01-30]. https://doi.org/10.3354/cr00918 
Matloff, N. (2017). Statistical Regression and Classification. Florida: Chapman and Hall/CRC. ISBN 978-1138066465.

Mann, H.B. (1945). Nonparametric tests against trend. Econometrica, 13(3), 245-259, [cit. 2021-01-25]. https://doi.org/10.2307/1907187

Martineau, P., Nakamura, H., Kosaka, Y. \& Yamamoto, A. (2020). Importance of a Vertically Tilting Structure for Energizing the North Atlantic Oscillation. Scientific Reports, 23(6), 1291-1307, [cit. 2020-01-15]. https://doi.org/10.1038/s41598-020-69551-5

Mika, J., Razsi, A. \& Gal, L. (2017). Climate Signal Detection in Wine Quality Using Gridded vs. Station Data in North-East Hungary. In European Geosciences Union General Assembly 2017, 23-28 April, 2017 in Vienna https://meetingorganizer.copernicus.org/EGU2017/posters/22763.

Mozell, M.R. \& Thach, L. (2014). The Impact of Climate Change on the Global Wine Industry: Challenges \& Solutions. Wine Economics and Policy, 3(2), 81-89, [cit. 2021-01-3]. https://doi.org/10.1016/j.wep.2014.08.001.

Navrátilová, M, Beranová, M, Severová, L, Šrédl, K, Svoboda, R. \& Abrahám, J. (2021). The Impact of Climate Change on the Sugar Content of Grapes and the Sustainability of their Production in the Czech Republic. Sustainability, 13(1), 118, [cit. 2021-02-10]. https://doi.org/10.3390/su13010222.

Nemani, R.R., White, M.A., Cayan, D.R., Jones, G.V., Rinning, S.W. \& Coughlan, J.C. (2001). Asymmetric Climatic Warming Improves California Vintages. Climate Research, 19(1), 25-34, [cit. 2021-01-20]. https://doi.org/10.3354/cr019025.

Pavloušek, P. (2009). Pěstujeme stolni odrůdy révy vinné. Praha: Grada Publishing, a.s., 120 p. ISBN 978-80-247-2787-5.

Pořizka, J. \& Diviš, P. (2018). Elemental Analysis as a Tool for Classification of Czech White Wines With Respect to Grapevine Varieties. Journal of Elementology, 23(2), 709-727, [cit. 2021-01-14] https://doi.org/10.5601/jelem.2017.22.4.1379.

Ramsey, J. B. (1969). Tests for Specification Errors in Classical Linear LeastSquares Regression Analysis. Journal of the Royal Statistical Society Series B, 31(2), 350-371. ISSN 1369-7412. https://doi.org/10.1111/j.25176161.1969.tb00796.x

Rožnovský, J., Fukalová, P., Chuchma, F. \& Středa, T. (2010). Dynamika podnebí Jižní Moravy ve vztahu k vymezení klimatických regionů. In Rožnovský, J., Litschmann, T. (ed). Voda v krajině, Lednice 31.5. - 1.6.2010. pp 47-56. ISBN 978-80-86690-79-7.

Shapiro, S.S. \& Wilk, M. B. (1965). An Analysis of Variance Test for Normality (complete samples). Biometrika, 52(3-4), 591-611, [cit. 2021-01-10]. https://doi.org/10.1093/biomet/52.3-4.591.

Salinger, M., Baldi, M., Grifoni, D., Jones, G., Bartoliny, G., Cecchi, S., Messeri, G., Marta, A., Orlandini, S., Dalu, G. \& Maracchi, G. (2015). Seasonal Differences in Climate in the Chianti Region of Tuscany and the Relationship to Vintage Wine Quality. International Journal of Biometeorology, 59(12), 17991811, [cit. 2021-01-23]. https://doi.org/10.1007/s00484-015-0988-8.

Soar, C.J., Sadras, V. \& Petrie, P. (2008). Climate drivers of red wine quality in four contrasting Australian wine regions. Australian Journal of Grape and Wine Research, 8, 14(2), 78-90, [cit. 2021-01-19]. https://doi.org/10.1111/j.17550238.2008.00011.x.

Storchmann, K. (2005). English weather and Rhine wine quality: an ordered probit model. Journal of Wine Research, 16(2), 105-119. https://doi.org/10.1080/09571260500327648.

White, M.A, Whalen, P. \& Jones, G.V. (2009). Land and Wine. Nature Geoscience, 2, 82-84, [cit. 2021-01-21]. https://doi.org/10.1038/ngeo429.

Winkler, A. J., Cook, J., Kliewer, W. \& Lider, L. (1974). General Viticulture. Berkeley: University of California Press. ISBN 978-0520025912.

Zahradníček, P. (2008). Fenologické fáze révy vinné v závislosti na meteorologických prvcích. In Rožnovský, J., Litschmann, T. (ed). Bioklimatologické aspekty hodnocení procesủ v krajinè, Mikulov 9. - 11.9.2008. ISBN 978-80-86690-55-1. 